\title{
RESPON PERTUMBUHAN STEK BATANG VANILI (Vanilla planifolia) TERHADAP LAMA PERENDAMAN ZAT PENGATUR TUMBUH ROOT MOST
}

\author{
Wilhelmus Haman dan Kristono Yohanes Fowo \\ Program Studi Agroteknologi, Fakultas Pertanian Universitas Flores Kampus I, \\ Jalan Sam Ratulangi XX-Paupire, Kabupaten Ende, Nusa Tenggara Timur \\ kristonoyf@gmail.com
}

\begin{abstract}
Growth of vanilla stone (vanilla planifolia) growth response on the duration of the root most growing arrangement. This study aims to determine the response of the immersion time of vanilla stem cuttings in the most root growth regulating agent and to know the length of soaking time of the vanilla stem cuttings in the most optimum root growth regulator. The design used in this study was a Completely Randomized Design (CRD) with six treatments soaking in minutes. Repeated four times, namely P1 (10 minutes), P2 (20 minutes), P3 (30 minutes), P4 (40 minutes), P5 (50 minutes), P6 (60 minutes). Variables observed including the number of days of first shoot growth, the number of roots, root length, shoot diameter, shoot length, wet weight of cuttings, and dry weight of cuttings. The results showed that the treatment of P6 gave a very significant effect. On the variable growth in the number of roots $(55.59 \%)$, root length $(58.86 \%)$, number of days of first shoot growth (28 days after planting), shoot diameter $(70.15 \%)$, shoot length $(71.43 \%)$, wet weight of cuttings $(37.14 \%)$ and dry weight of cuttings $(65.04 \%)$ at each age of observation.
\end{abstract}

Keywords: Growth response, Root most, Vanilla

\section{PENDAHULUAN}

\section{Latar Belakang}

Vanili (Vanilla planifolia) termasuk dalam famili Orchidaceae (bangsa anggrek) yang berasal dari Meksiko dan masuk ke Indonesia sekitar tahun 1819. Buah tanaman vanili banyak digunakan dalam industri makanan, minuman, farmasi dan kosmetik karena buahnya mengandung vanillin $\left(\mathrm{C}_{8} \mathrm{H}_{8} \mathrm{O}_{3}\right)$ yang mengeluarkan aroma khas. Tanaman vanili telah menyebar luas hampir di seluruh wilayah di Indonesia dengan daerah sentral produksi di daerah Jawa, Bali, Sulawesi dan Sumatera yang selanjutnya menempatkan vanili sebagai komoditi ekspor yang bernilai tinggi dan berpotensi dalam penerimaan devisa negara (Udarno dan Hadipoentyanti, 2009 dalam Hidayat dan Hariyadi, 2015).

Produksi vanili di NTT pada tahun 2014 mencapai 444 ton namun di tahun 2015 terjadi penurunan dengan rata-rata produksi sebesar 401 ton (BPS NTT, 2015), sedangkan untuk di Kabupaten Ende 
produksi vanili pada tahun 2014 mencapai 60 ton, akan tetapi pada tahun 2015 terjadi penurunan produksi sebesar 13 ton dimana produksi vanili hanya mencapai 47 ton (BPS Kabupaten Ende, 2015).

Penurunan produksi vanili terjadi karena teknik budidaya yang kurang baik, salah satunya adalah kurangnya perlakuan awal yang menyebabkan lamanya pertumbuhan tunas dari stek tanaman vanili saat pembibitan. Penanaman secara vegetatif memiliki banyak kendala seperti lamanya pertumbuhan akar dan tunas dari stek (Irama, 2006 dalam Supardi dan Seda, 2010) oleh karena itu perlu penggunaan pupuk organik maupun zat pengatur tumbuh untuk merangsang pertumbuhan stek baik pertumbuhan akar maupun tunas. Zat pengatur tumbuh yang dapat digunakan salah satunya adalah ZPT Root Most yang termasuk dalam pupuk organik cair dan ZPT (Basmal, 2009). Lingga (1989) mengungkapkan bahwa setiap tanaman memerlukan 16 unsur untuk pertumbuhan tanaman yang normal, 3 diantaranya adalah unsur karbon, hidrogen, dan oksigen yang diperoleh dari udara, serta 13 unsur disediakan oleh tanah seperti N, P, K, Ca, Mg, S, $\mathrm{Cl}, \mathrm{Fe}, \mathrm{Mn}, \mathrm{Cu}, \mathrm{Zn}, \mathrm{B}$, dan Mo.

Zat Pengatur Tumbuh Root Most $90 \%$ unsurnya merupakan nutrisi bagi tanaman dan berguna untuk mendorong pertumbuhan akar sehingga mampu meningkatkan penyerapan unsur hara oleh tanaman, dan berbahan aktif ekstrak rumput laut yang dilengkapi dengan hormon pertumbuhan seperti auksin, sitokinin dan giberlin (Basmal, 2009) yang dapat merangsang pertumbuhan akar, mendorong pertumbuhan akar utama, akar sekunder dan bulu-bulu akar serta meningkatkan penyerapan unsur hara dalam tanah oleh tanaman, meningkatkan kesuburan tanah dan memperbaiki keadaan fisik dan kimia tanah, membantu tanaman menyerap dan mengasimilasi zat pengatur tumbuh, meningkatkan ketahanan bibit tanaman ketika pindah tanam, mempersingkat waktu perendaman benih dan membantu peroses perkecambahan, memperpanjang dan mempertebal akar serta memperluas daerah perakaran, tidak beracun dan aman bagi lingkungan. Kandungan unsur hara dalam Root Most terdiri atas unsur hara mikro $\mathrm{Zn} \mathrm{(Zinc),} \mathrm{Cu}$ (Cuprum), Mn (Mangan), B (Boron), $\mathrm{Fe}$ (Besi), dan kandungan unsur hara makro meliputi C-organik, pH, Co, dan Mo (Anonim, 2010).

Anjuran pada produk ZPT root most menerangkan bahwa untuk pencelupan stek tanaman dibutuhkan $2 \mathrm{ml}$ root most yang diencerkan dalam 1 liter air (Anonim, 2010), namun belum diketahui lama perendaman bahan stek dalam root most yang dapat meningkatkan pertumbuhan dan perkembangan stek tanaman yang optimum.

Hasil penelitian Supardi dan Seda (2010) pada perlakuan ZPT 
Rootone-F membuktikan bahwa lama waktu perendaman selama 15 menit memberikan hasil pertumbuhan akar terbaik yang ditunjukkan melalui jumlah akar terbanyak (3,08 buah), dengan panjang akar $(10,98 \mathrm{~cm})$ dan mempercepat pertumbuhan tunas yang di tunjukkan melalui jumlah hari tumbuh tunas pertama tercepat (15,66 hari), jumlah tunas terbanyak (2,33 buah), panjang tunas $(5,23 \mathrm{~cm})$, berat basah $(217,44$ gr) serta berat kering tertinggi $(32,06$ gr) pada 28 HST. Dari hasil penelitian tersebut maka penggunaan ZPT root most merupakan alternatif dalam pertumbuhan dan perkembangan stek batang vanili, namun diperlukan juga ketepatan lama waktu perendaman dalam pengaplikasiannya di lapangan.

\section{METODE PENELITIAN}

\section{Tempat dan Waktu pelaksana}

Penelitian dilaksanakan di kebun Percobaan Fakultas Pertanian Universitas Flores, di kelurahan Lokoboko, kecamatan Ndona, kabupaten Ende. Dengan ketinggian tempat $500 \mathrm{~m}$ dpl, kelembaban $30 \%$, suhu $30-32{ }^{0} \mathrm{C}$, kondisi tanah dikebun percobaan memiliki $\mathrm{pH}$ tanah 6,5, COrganik tergolong rendah dengan nilai $0,17 \%, \mathrm{P}$ tersedia tergolong sedang dengan nilai $10,94 \% \mathrm{mg}$, Ktersedia tergolong sedang dengan nilai $0,36 \mathrm{me} / 100 \mathrm{~g}$ dan memiliki tekstur tanah pasir berlempung (Tage, 2012). Penelitian dilaksanakan selama 6 bulan.

\section{Bahan dan Alat}

Bahan yang digunakan dalam penelitian ini adalah stek batang vanili, ZPT root most, air, media semai stek, paranet, lilin, bambu. Sedangkan alat yang digunakan meliputi polybag ukuran $15 \mathrm{~cm}$ x 20 $\mathrm{cm}$, gunting pangkas, ember plastik, sendok, gelas, gembor, oven, meteran, mistar, timbangan analitik, jangka sorong, kamera dan alat tulis menulis.

\section{Rancangan Penelitian}

Rancangan yang digunakan dalam penelitian ini adalah Rancangan Acak Lengkap (RAL) dengan pola faktor tunggal yang terdiri dari 6 perlakuan lama perendaman dan menggunakan ZPT dengan perbandingan $2 \mathrm{ml} /$ liter air yaitu P1 (10 menit), P2 (20 menit), P3 (30 menit), P4 (40 menit), P5 (50 menit), P6 (60 menit). Setiap perlakuan diulang 4 kali, masingmasing perlakuan terdiri dari 6 polibag untuk tanaman sampel sehingga terdapat 244 polibag.

\section{Pelaksanaan Penelitian \\ Persiapan Stek}

Stek diambil dari cabang muda yang berumur $<1$ tahun, panjang stek $30 \mathrm{~cm} / 3$ ruas, belum pernah berbunga atau berbuah (Samadi, 2009).

\section{Persiapan Media}

Media tanam terdiri dari pasir dan pupuk organik (kompos) yang sudah diayak menggunakan ayakan 
halus dan dicampur dengan perbandingan (1:1:1), campuran media dimasukkan ke dalam polibeg dan diletakan pada tempat pembibitan yang sudah diberi penaungan dari paranet untuk menjaga kondisi media tanam tetap lembab.

\section{Perendaman}

$\begin{array}{ccr}\text { Bahan stek yang telah } \\ \text { disiapkan, } & \text { diikat }\end{array}$ menggunakan karet gelang kemudian direndam dalam larutan sesuai anjuran kemudian diberi label lama perendaman. Stek di rendam pada bagian pangkal, perendaman stek dilakukan pada wadah yang berbeda sesuai dengan perlakuan yang diberikan.

\section{Penanaman dan Pemeliharaan}

Sebelum penanaman, media tanam disiram terlebih dahulu untuk memudahkan proses penanaman. Penanaman stek vanili dilakukan dengan cara stek dipindahkan ke media tanam yang sudah disiapkan, lalu media tanam dalam polibek dibuat lubang terlebih dahulu, masukan pangkal stek ke dalam lubang sepanjang minimal satu ruas. Pemeliharaan meliputi: penyiraman, penyulaman dan penyiangan gulma.

\section{Variabel Pengamatan}

Pengamatan dilakukan secara destruktif/membongkar yakni dengan cara polibag disobek, kemudian disemprot dengan air pada bagian sobekan sampai media tanam terpisah dari perakaran. Pengamatan dilakukan pada tanaman sampel yang dilakukan pada umur 4, 8, 12 MST (Minggu Setelah Tanam), untuk setiap pengamatan masing-masing 2 tanaman sampel dan variabel yang diamati dalam penelitian ini adalah:

1. Jumlah Akar (helai): Pengamatan jumlah akar dilakukan dengan cara destruktif (mencabut) kemudian dilakukan penghitungan seluruh akar yang terdapat pada stek vanili yang diberi perlakuan.

2. Panjang Akar (cm): Pengamatan panjang akar dilakukan dengan cara destruktif (mencabut) kemudian dilakukan pengukuran seluruh akar yang terdapat pada stek vanili menggunakan mistar.

3. Jumlah Hari Tumbuh Tunas Pertama (tunas): Hari tumbuh tunas pertama dilihat dari awal penanaman pertama samapai hari tumbuh tunas.

4. Diameter Tunas (mm): Pengamatan diameter tunas dilakukan pengukuran menggunakan jangka sorong.

5. Panjang Tunas $(\mathrm{cm})$ : Panjang tunas dihitung dengan mengukur panjang tunas yang terbentuk dari setiap stek dan diukur menggunakan meteran atau mistar.

6. Berat Basah Stek Vanili: Pengamatan berat basah stek vanili dilakukan dengan cara destruktif (mencabut) yang didahului dengan membuka salah satu sisi polibek dengan cara disobek, setelah itu disemprot 
dengan menggunakan air samapai media tanah terpisah dari perakaran tanaman vanili, pisahkan stek dengan akar lalu lakukan penimbangan menggunakan timbangan analitik.

7. Berat Kering Stek Vanili: Berat kering stek diperoleh dengan cara bagian tanaman dipisahkan batang dan daun. Setelah itu, dimasukan dalam amplop dan di oven dengan suhu $80^{\circ} \mathrm{C}$ sampai diperoleh berat konstan, setelah itu bagian tanaman ditimbang dengan menggunakan timbangan Analitik.

\subsection{Analisis Data}

Data dianalisis dengan sidik ragam yang digunakan. Apabila perlakuan menunjukan pengaruh nyata terhadap variabel yang diamati maka dilanjutkan dengan uji BNT Taraf $5 \%$ (Gomez dan Gomez, 1995).

\section{HASIL DAN PEMBAHASAN}

Hasil

Analisis statistik respon pertumbuhan stek batang vanili (Vanilla planifolia) terhadap lama perendaman zat pengatur tumbuh root most ditunjukkan Table 1 .

Tabel 1. Signifikasi Respon Pertumbuhan Stek Batang Vanili Akibat Lama Perendaman Zat Pengatur Tumbuh Root Most.

\begin{tabular}{clc}
\hline No & \multicolumn{1}{c}{ Variabel } & Keterangan \\
\hline 1 & Jumlah Hari Tumbuh Tunas & $* *$ \\
2 & Jumlah Akar 4 Mst & $* *$ \\
3 & Jumlah Akar 8 Mst & $* *$ \\
4 & Jumlah Akar 12 Mst & $* *$ \\
5 & Panjang Akar 4 Mst & $* *$ \\
6 & Panjang Akar 8 Mst & $* *$ \\
7 & Panjang Akar 12 Mst & $* *$ \\
8 & Diameter Tunas 4 Mst & $* *$ \\
9 & Diameter Tunas 8 Mst & $* *$ \\
10 & Diameter Tunas 12 Mst & $* *$ \\
11 & Panjang Tunas 4 Mst & $* *$ \\
12 & Panjang Tunas 8 Mst & $* *$ \\
13 & Panjang Tunas 12 Mst & $* *$ \\
14 & Berat Basah Stek 4 Mst & $* *$ \\
15 & Berat Basah Stek 8 Mst & $* *$ \\
16 & Berat Basah Stek 12 Mst & $* *$ \\
17 & Berat Kering Stek 4 Mst & $* *$ \\
18 & Berat Kering Stek 8 Mst & $*$ \\
19 & Berat Kering Stek 12 Mst & $* *$ \\
\hline MST: Minggu Setelah Tanam; $*$ Nyata; $* *:$ Sangat Nyata
\end{tabular}

\section{PEMBAHASAN}


Variabel Pertumbuhan Jumlah Akar (helai) dan Panjang Akar (cm)

Hasil analisis statistik lama perendaman ZPT Root Most berpengaruh sangat nyata terhadap variabel jumlah akar dan panjang akar yang ditunjukan pada Table 2 . menunjukkan bahwa perbedaan waku

Tabel 2. Respon Pertumbuhan Stek Batang Vanili (Vanilla planifolia) Akibat Lama Perendaman Zat Pengatur Tumbuh Root Most Terhadap Variabel Jumlah Akar dan Panjang Akar.

\begin{tabular}{ccccc}
\hline \multirow{2}{*}{ Variabel } & \multirow{2}{*}{ Perlakuan } & \multicolumn{3}{c}{ Umur Pengamatan Mst } \\
\cline { 2 - 5 } & & 4 & 8 & 12 \\
\hline Jumlah & P1 & $1,63 \mathrm{a}$ & $1,88 \mathrm{a}$ & $5,13 \mathrm{a}$ \\
Akar & P2 & $1,88 \mathrm{a}$ & $2,50 \mathrm{a}$ & $6,00 \mathrm{a}$ \\
& P3 & $2,00 \mathrm{a}$ & $2,38 \mathrm{a}$ & $7,13 \mathrm{~b}$ \\
& P4 & $2,00 \mathrm{ab}$ & $2,63 \mathrm{ab}$ & $7,88 \mathrm{ab}$ \\
& P5 & $2,00 \mathrm{~b}$ & $4,25 \mathrm{c}$ & $8,75 \mathrm{~b}$ \\
& P6 & $3,00 \mathrm{c}$ & $6,00 \mathrm{~d}$ & $10,63 \mathrm{c}$ \\
\hline BNT 5\% & & 0,63 & 0,89 & 1,92 \\
Panjang & P1 & $5,44 \mathrm{a}$ & $5,77 \mathrm{a}$ & $6,42 \mathrm{a}$ \\
Akar & P2 & $5,67 \mathrm{a}$ & $6,19 \mathrm{a}$ & $6,57 \mathrm{a}$ \\
& P3 & $7,78 \mathrm{~b}$ & $6,75 \mathrm{a}$ & $8,21 \mathrm{a}$ \\
& P4 & $7,38 \mathrm{ab}$ & $8,22 \mathrm{ab}$ & $8,36 \mathrm{ab}$ \\
& P5 & $11,25 \mathrm{bc}$ & $13,18 \mathrm{c}$ & $10,27 \mathrm{~b}$ \\
& P6 & $12,88 \mathrm{c}$ & $17,75 \mathrm{~d}$ & $12,22 \mathrm{c}$ \\
\hline BNT 5\% & & 3,11 & 4,82 & 3,27 \\
\hline
\end{tabular}

Keterangan: Angka-angka yang diikuti oleh huruf yang sama pada umur pengamatan yang sama menunjukkan tidak berbeda nyata pada uji BNT5\%.

Tabel 2 menunjukkan respon pertumbuhan stek batang vanili akibat perlakuan lama waktu perendaman zat pengatur tumbuh Root Most terhadap rata-rata pertumbuhan pada variabel pengamatan jumlah akar dan panjang akar berpengaruh sangat nyata untuk semua umur pengamatan.

Jumlah akar terbanyak dan panjang akar yang terpanjang diperoleh pada perlakuan lama perendaman 60 menit (P6) dengan persentase jumlah akar 55,99\% dan panjang akar $58,86 \%$ pada umur $4 ; 8$; 12 minggu setelah tanam. Peningkatan perlakuan lama perendaman yang ditunjukkan pada Tabel 2 dapat disimpulkan bahwa hipotesis 1 diterima yakni perbedaan lama waktu perendaman memberikan respon pertumbuhan yang berbeda pada stek tanaman vanili. Dimana peningkatan lama waktu perendaman 
dari p1 (10 menit) ditingkatkan ke P2 (20 menit); P2 (20 menit) ke P3 (30 menit); P3 (30 menit) ke P4 (40 menit); P4 (40 menit) ke P5 (50 menit); P5 (50 menit) ke P6 (60 menit), dengan persentase $16,76 \%$; $29,53 \% ; 26,53 \%$; 42,40\%; 55,99\%. Hal yang sama juga diikuti dengan panjang akar dari P1 ditingkatkan ke P2; P2 ke P3 ; P3 ke P4 ; P4 ke P5; P5 ke P6, dengan persentase 4,34\%; $22,47 \%$; $26,42 \%$; 49,19\%; $58,86 \%$ atau secara keseluruhan mengalami peningkatan.

Pada umur pengamatan 4 dan 12 minggu setelah tanam untuk variabel jumlah akar, perlakuan lama perendaman P5 tidak berbeda nyata dengan perlakuan $\mathrm{P} 4$ terkecuali pada perlakuan P1; P2; P3 dan P6, pada umur pengamatan 8 minggu setelah tanam perlakuan $\mathrm{P} 4$ tidak berbeda nyata dengan perlakuan P1; P2; P3 terkecuali pada perlakuan P5 dan P6. Hal yang berbeda terjadi pada variabel panjang akar, dimana pada umur pengamatan 4 minggu setelah tanam perlakuan P6 tidak berbeda nyata dengan perlakuan P5 terkecuali pada perlakuan P1; P2; P3 dan P4, umur pengamatan 8 setelah tanam perlakuan P5 berbeda nyata dengan dengan semua perlakuan. Perlakuan P1 tidak berbeda nyata dengan P2; P3 dan P4 terkecuali pada perlakuan P5; P6. Umur pengamatan 12 minggu setelah tanam perlakuan P5 tidak berbeda nyata dengan perlakuan P4 terkecuali pada P1; P2; P3; P6 dan lama perendaman $\mathrm{P} 1$ tidak berbeda nyata dengan perlakuan $\mathrm{P} 2 ; \mathrm{P} 3$; P4 terkecuali pada P5 dan P6. Hal ini disebabkan karena setelah perendaman dan penanaman stek pada media tanam tidak didukung oleh faktor lingkungan yakni curah hujan yang tinggi sehingga mempengaruhi suhu dan kelembapan. Data curah hujan pada bulan Nopember hingga bulan April mencapai $2.171 \mathrm{~mm}$, suhu terendah mencapai pada titik $23^{\circ} \mathrm{C}$ dan kelembaan berada dalam kisaran rata-rata 85\% (BMKG Kabupaten Ende, 2019).

Samadi

mengungkapkan tanamana Vanili dapat tumbuh pada ketinggian tempat yang ideal 400-700 m dpl, dengan suhu optimum $20^{\circ} \mathrm{C}$ dengan kelembapan udara 70-80\% (rata-rata $75 \%$, curah hujan 1.500-2.000 mm/tahun dengan bulan kering 3-4, intensitas cahaya antara 30-50\%, suhu optium $20^{\circ} \mathrm{C}$.

Hal ini juga didukung oleh pendapat Salisburi dan Ross (1995) yang mengatakan bahwa perkembangan tumbuhan sangat dipengaruhi oleh suhu dan kelembaban. Perubahan beberapa derajat menyebabkan perubahan yang nyata dalam laju pertumbuhan pada tahap tertentu dalam daur hidupnya dan pada kondisi kajian tertentu tiap spesies atau varietas mempunyai suhu minimum, rentang suhu optimum dan suhu maksimum. Di bawah suhu minimum laju pertumbuhannya paling tinggi dan di 
atas suhu maksimum tumbuhan tidak tumbuh bahkan mati.

Walaupun demikian saat perendaman stek jaringan tanaman mengabsorsi air beserta zat-zat yang terkandung dalam ZPT Root Most yang mengandung auksin serta berfungsi untuk mendorong perpanjangan sel, pembelahan sel, diferensiasi jaringan xylem dan floem sehingga stek masih mampu untuk bertahan hidup dan jumlah akar maupun panjang akar terjadi signifikan yang ditandai dengan banyaknya jumlah akar dan panjang akar pada stek.

Hal ini sejalan dengan penelitian Dwijoseputro dalam Supardi dan Seda, (2010) yang mengatakan bahwa kehadiran tunas pada stek akan membantu proses pembentukan zat pengatur tumbuh yang kemudian diedarkan ke bagian bawah untuk pembentukan akar. Kusumo (1984) dalam Firmansyah dkk. (2014) juga menjelaskan bahwa zat pengatur tumbuh yang dapat meningkatkan keberhasilan perbanyakan bibit melalui stek adalah hormon tumbuh auksin yang dapat menstimulir pembentukan akar adventif pada stek. Hal tersebut juga diperkuat oleh hasil penelitian Mulyani dan Ismail (2015), yang mengatakan bahwa lama perendaman membuat stek dapat menyerap larutan hormon sampai batas optimum yang dibutuhkan oleh tanaman untuk pertumbuhan dan perkembangan akar, perendaman selama 3 jam (waktu paling lama dalam penelitiannya) dalam larutan Rootone-F memberikan pengaruh yang paling nyata terhadap jumlah akar (7,63 helai) dan panjang akar $(4,21 \mathrm{~cm})$.

\subsubsection{Variabel Pertumbuhan Jumlah Hari Tumbuh Tunas (Hari)}

Dari hasil analisis statistik variabel pertumbuhan jumlah hari tumbuh tunas menunjukkan bahwa perbedaan lama waku perendaman ZPT Root Most berpengaruh sangat nyata yang ditunjukan pada Tabel 3 .

Pada Tabel 3 terlihat bahwa respon pertumbuhan stek batang vanili akibat perlakuan lama waktu perendaman zat pengatur tumbuh Root Most terhadap rata-rata pertumbuhan pada variabel pengamatan jumlah hari tumbuh tunas berpengaruh sangat nyata. Jumlah hari tumbuh tunas tercepat pada perlakuan lama perendaman 60 menit (P6) dan jumlah hari tumbuh tunas terlama pada perlakuan 10 menit (P1). Respon pertumbuhan vanili dalam ZPT Root Most yang ditunjukkan pada Tabel 3 dapat disimpulkan bahwa hipotesis 2 terjawap yakni semakin lama waktu perendaman maka semakin optimal pertumbuhan akar dan tunas tanaman vanili. Walaupun Perlakuan P5 (50 menit) tidak berbeda nyata dengan perlakuan P4 (40 menit) dan P3 (30 menit), terkecuali pada perlakuan lama perendaman P1 (10 menit) dan P2 (20 menit). Hal ini disebabkan 
karena lama perendaman zat giberlin dapat merangsang pengatur tumbuh Root Most yang pertumbuhan tunas menjadi lebih mengandung auksin, sitokinin dan cepat.

Tabel 3. Respon Pertumbuhan Stek Batang Vanili (Vanilla planifolia) Akibat Lama Perendaman Zat Pengatur Tumbuh Root Most Terhadap Variabel Jumlah Hari Tumbuh Tunas.

\begin{tabular}{ccc}
\hline \multicolumn{1}{c}{ Variabel } & Perlakuan & Rataan \\
\hline & P1 & $23,13 \mathrm{a}$ \\
Jumlah Hari Tumbuh & P2 & $21,50 \mathrm{a}$ \\
Tunas (hari) & P4 & $19,38 \mathrm{ab}$ \\
& P5 & $17,50 \mathrm{~b}$ \\
& P6 & $15,63 \mathrm{~b}$ \\
\hline BNT 5\% & & $2,08 \mathrm{c}$ \\
\hline
\end{tabular}

Keterangan: Angka-angka yang diikuti oleh huruf yang sama pada kolom yang sama berarti tidak berbeda nyata pada unji BNT 5\%.

Hal ini sejalan dengan penelitian Supardi dan Seda (2010) bahwa waktu perendaman 15 menit (waktu paling lama dalam penelitiannya) menggunakan Rootone-F membantu pertumbuhan tunas dalam hal membuat tunas yang muncul pada stek vanili semakin cepat karena banyaknya zat pengatur tumbuh yang diserap oleh stek vanili. Kusumo (1984) dalam Suprapto (2004) mengatakan sitokinin merupakan suatu zat di dalam tanaman yang bersama dengan auksin dalam menentukan arah terjadinya deferensiasi sel. Keefektifan sitokinin sangat bervariasi diantaranya ditentukan oleh dosis yang digunakan serta lama waktu perendaman, umur dan bagian tanaman yang digunakan.

\subsubsection{Variabel Pertumbuhan \\ Diameter Tunas (mm) dan Panjang Tunas (cm) \\ Hasil analisis statistik} menunjukkan bahwa perbedaan lama waku perendaman ZPT Root Most berpengaruh sangat nyata terhadap variabel diameter tunas dan panjang tunas, dimana perlakuan lama perendaman 60 menit (P6) menunjukkan rata-rata diameter tunas maupun panjang tunas tertinggi danvariabel diameter tunas maupun panjang tunas terendah pada perlakuan 10 menit (P1) yang ditunjukkan pada Tabel 4.

Tabel 4. Respon Pertumbuhan Stek Batang Vanili (Vanilla planifolia) Akibat Lama Perendaman Zat Pengatur Tumbuh Root Most Terhadap Variabel Diameter Tunas dan Panjang Tunas. 


\begin{tabular}{ccccc}
\hline \multirow{2}{*}{ Variabel } & \multirow{2}{*}{ Perlakuan } & \multicolumn{3}{c}{ Umur Pengamatan mst } \\
\cline { 3 - 5 } & & 4 & 8 & 12 \\
\hline Diameter & P1 & $0,46 \mathrm{a}$ & $0,26 \mathrm{a}$ & $0,28 \mathrm{a}$ \\
Tunas & P2 & $0,73 \mathrm{ab}$ & $0,26 \mathrm{a}$ & $0,33 \mathrm{a}$ \\
& P3 & $0,71 \mathrm{a}$ & $0,28 \mathrm{a}$ & $0,35 \mathrm{ab}$ \\
& P4 & $0,88 \mathrm{~b}$ & $0,28 \mathrm{ab}$ & $0,34 \mathrm{a}$ \\
& P5 & $1,69 \mathrm{bc}$ & $0,34 \mathrm{~b}$ & $0,39 \mathrm{~b}$ \\
& P6 & $2,44 \mathrm{~d}$ & $0,40 \mathrm{c}$ & $0,51 \mathrm{c}$ \\
\hline BNT 5\% & & 0,64 & 0,06 & 0,07 \\
\hline Panjang & P1 & $3,00 \mathrm{a}$ & $8,06 \mathrm{a}$ & $20,50 \mathrm{a}$ \\
Tunas & P2 & $3,48 \mathrm{a}$ & $10,69 \mathrm{a}$ & $28,63 \mathrm{a}$ \\
& P3 & $3,50 \mathrm{ab}$ & $10,94 \mathrm{a}$ & $33,50 \mathrm{a}$ \\
& $\mathrm{P} 4$ & $4,69 \mathrm{~b}$ & $13,38 \mathrm{ab}$ & $35,13 \mathrm{ab}$ \\
& $\mathrm{P} 5$ & $5,41 \mathrm{bc}$ & $22,25 \mathrm{c}$ & $42,63 \mathrm{~b}$ \\
& P6 & $7,10 \mathrm{c}$ & $31,50 \mathrm{~d}$ & $61,38 \mathrm{c}$ \\
\hline BNT 5\% & & 1,85 & 4,59 & 9,70 \\
\hline
\end{tabular}

Keterangan: Angka-angka yang diikuti oleh huruf yang sama pada umur pengamatan yang sama berarti tidak berbeda nyata padauji BNT 5 $\%$.

Pada Tabel 4 terlihat bahwa respon pertumbuhan stek batang vanili akibat perlakuan lama perendaman zat pengatur tumbuh Root Most terhadap rata-rata pertumbuhan pada variabel pengamatan diameter tunas dan panjang tunas berpengaruh sangat nyata. Perlakuan lama perendaman zat pengatur tumbuh Root Most yang paling tinggi pada variabel diameter tunas terbesarmaupun panjang tunas terpanjang terdapat pada perlakuanlama perendaman 60 menit (P6) dengan persentase $(70,15 \%)$; $(71,43 \%)$ dan perlakuan lama perendaman zat pengatur tumbuh Root Most yang paling rendah pada variabel diameter tunas terkecil dan panjang tunas terpendek diperoleh pada perlakuan P1 (10 menit).
Respon pertumbuhan stek batang vanili yang ditunjukkan pada Tabel 4 dapat disimpulkan bahwa hipotesis 2 terjawab yang mengatakan bahwa semakin lama waktu perendaman maka semakin optimal pertumbuhan akar dan tunas tanaman vanili. Dimana peningkatan lama waktu perendaman dari P1 (10 menit) ditingkatkan ke P2 (20 menit); P2 (20 menit) ke P3 (30 menit); P3 (30 menit) ke P4 (40 menit); P4 (40 menit) ke P5 (50 menit) dan P5 (50 menit) ke P6 (60 menit) dengan persentase diameter tunas $32,00 \%$; $25,37 \%$; 33,33\%; 58,68\%; 71,43\%. Demikian juga pada variabel pengamatan panjang tunasdimana perlakuan P1 ditingkatkan ke P2; P2 ke P3; P3 ke P4; P4 ke P5 dan P5 ke P6 memberikan persentase panjang 
tunas sebesar $0,09 \% ; 33,26 \%$; $46,31 \% ; 58,86 \% ; 71,43 \%$.

Umur pengamatan 4 minggu setelah tanam variabel diameter tunas Perlakuan P3 tidak berbeda nyata dengan perlakuan P1 dan P2 kecuali pada perlakuan P4; P5 dan P6, perlakuan P5 tidak berbeda nyata dengan P4 dan P2 kecuali pada perlakuan P1; P3 dan P6. Pada umur pengamatan 8 dan 12 minggu setelah tanam perlakuan P5 tidak berbeda nyata dengan perlakuan P1; P2; P3; P4 terkecuali pada perlakuan P6.

Hal yang berbeda terjadi pada variabel panjang tunas pada umur pengamatan 4 minggu setelah tanam dimana perlakuan P5 tidak berbeda nyata dengan perlakuan $\mathrm{P} 3$ dan $\mathrm{P} 4$ terkecuali pada P1; P2 dan P6, perlakuan lama perendaman P3 tidak berbeda nyata dengan perlakuan P2 dan P1 terkecuali pada perlakuan P4; P5; P6. Umur pengamatan 8 minggu setelah tanam perlakuan P5 berbeda nyata dengan semua perlakuan dan perlakuan P4 tidak berbeda nyata dengan perlakuan P3; P2; P1 terkecuali pada perlakuan P5 dan P6. Pada umur pengamatan 12 minggu setelah tanam P5 tidak berbeda nyata dengan P4 terkecuali dengan perlakuan P1; P2; P3 dan P6, perlakuan P1 tidak berbeda nyata dengan perlakuan P2; P3 dan P4 terkecuali pada perlakuan P5 dan P6. Hal ini disebabkan karena setelah perendaman dan penanaman stek pada media tanam tidak didukung oleh faktor lingkungan yakni curah hujan yang tinggi sehingga mempengaruhi suhu dan kelembaban. Data curah hujan pada bulan Nopember hingga bulan April mencapai $2.171 \mathrm{~mm}$, suhu terendah mencapai pada titik $23^{0} \mathrm{C}$ dan kelembaban berada dalam kisaran rata-rata 85\% (BMKG Kabupaten Ende, 2019).

Samadi

mengungkapkan tanamana Vanili dapat tumbuh pada ketinggian tempat yang ideal 400-700 m dpl, dengan suhu optimum $20^{\circ} \mathrm{C}$ dengan kelembaban udara 70-80\% (rata-rata $75 \%$, curah hujan 1.500-2.000 $\mathrm{mm} /$ tahun dengan bulan kering 3-4, intensitas cahaya antara 30-50\%, suhu optium $20^{\circ} \mathrm{C}$. Hal ini juga didukung oleh pendapat Salisburi dan Ross (1995) yang mengatakan bahwa perkembangan tumbuhan sangat dipengaruhi oleh suhu dan kelembaban. Perubahan beberapa derajat menyebabkan perubahan yang nyata dalam laju pertumbuhan pada tahap tertentu dalam daur hidupnya dan pada kondisi kajian tertentu tiap spesies atau varietas mempunyai suhu minimum, suhu optimum dan suhu maksimum. Di bawah suhu minimum laju pertumbuhannya paling tinggi dan di atas suhu maksimum tumbuhan tidak tumbuh bahkan mati.

Walaupun demikian lamanya waktu saat perendaman stek membuat jaringan tanaman mampu mengabsorsi air beserta zat-zat yang terkandung dalam ZPT Root Most 
yang mengandung auksin serta berfungsi untuk mendorong perpanjangan sel, pembelahan sel, diferensiasi jaringan xylem dan floem sehingga stek masih mampu untuk bertahan hidup dan diameter tunas maupun panjang tunas terjadi signifikan yang ditandai dengan besarnya diameter tunas dan tunas terpanjang pada stek.

Hal ini setara dengan penelitian Supardi dan Seda (2010) yang mengatakan bahwa pemberian ZPT Rootone-F dengan waktu perendaman 15 menit (paling lama dalam penelitiannya) diangkut melalui jaringan floem ke dasar potongan vanili akan pembentukan akar dan tunas yang kuat dan juga mengakibatkan pertumbuhan yang kuat pula sehingga proses perpanjangan tunas dan diameter tunas dapat terjadi dengan baik.

\subsubsection{Variabel Pertumbuhan Berat Basah Stek (g) dan Berat Kering Stek (g)}

Hasil analisis statistik menunjukkan bahwa perbedaan lama waku perendaman ZPT root most berpengaruh sangat nyata terhadap variabel berat basah stek dan berat kering stekyang ditunjukan pada Tabel 5.

Berdasarkan Tabel 5 dapat dijelaskan bahwa perlakuan lama perendaman zat pengatur tumbuh Root Most yang peling tinggi pada variabel berat basah stek maupun berat kering stek terdapat pada perlakuan lama perendaman 60 menit (P6) dengan persentase berat basah stek sebesar $37,14 \%$ dan berat kering stek sebesar $59,57 \%$, berat basah stek maupun berat kering stek terendah diperoleh pada perlakuan 10 menit (P1). Peningkatan perlakuan lama waktu perendaman yang ditunjukkan pada tabel 5 menunjukkan bahwa hipotesis 1 terjawab yakni perbedaan lama perendaman memberikan respon pertumbuhan yang berbeda pada stek tanaman vanili. Dimana peningkatan lama waktu perendaman pada variabel berat basah dari P1 (10 menit) ditingkatkan ke P2 (20 menit); P2 (20 menit) ke P3 (30 menit); P3 (30 menit) ke P4 (40 menit); P4 (40 menit) ke P5 (50 menit) dan P5 (50 menit) ke P6 (60 menit) dengan persentasesebesar $\quad 0,23 \% ; 3,44 \%$; $12,67 \%$; $28,44 \%$ dan $37,14 \%$. Hal yang sama juga diikuti dengan variabel berat basah stek dimana P1 ditingkatkan ke P2; P2 ke P3; P3 ke P4; P4 ke P5 ; P5 ke P6 dengan persentase sebesar 13,64\%; 30,08\%; $31,13 \% ; 47,77 \%$ dan $59,57 \%$.

Tabel 5. Respon Pertumbuhan Stek Batang Vanili (Vanilla planifolia) Akibat Lama Perendaman Zat Pengatur Tumbuh Root Most Terhadap Variabel Berat Basah Stek (g) dan Berat Kering Stek (g) 


\begin{tabular}{|c|c|c|c|c|}
\hline \multirow{2}{*}{ Variabel } & \multirow{2}{*}{ Perlakuan } & \multicolumn{3}{|c|}{ Umur Pengamatan mst } \\
\hline & & 4 & 8 & 12 \\
\hline Berat Basah & $\mathrm{P} 1$ & $18,25 \mathrm{a}$ & $22,50 \mathrm{a}$ & $24,75 \mathrm{a}$ \\
\hline \multirow[t]{5}{*}{ Stek } & $\mathrm{P} 2$ & $18,15 \mathrm{a}$ & $21,13 \mathrm{a}$ & 26,38 a \\
\hline & P3 & $19,45 \mathrm{a}$ & $20,63 \mathrm{a}$ & $27,75 \mathrm{ab}$ \\
\hline & P4 & $21,75 \mathrm{~b}$ & $23,75 \mathrm{ab}$ & $29,50 \mathrm{~b}$ \\
\hline & P5 & $24,40 \mathrm{bc}$ & $32,50 \mathrm{c}$ & $34,63 \mathrm{bc}$ \\
\hline & P6 & $25,95 \mathrm{c}$ & $38,75 \mathrm{c}$ & $39,50 \mathrm{~d}$ \\
\hline BNT 5\% & & 2,40 & 7,20 & 2,14 \\
\hline Berat Kering & $\mathrm{P} 1$ & $1,00 \mathrm{a}$ & $1,50 \mathrm{a}$ & $5,75 \mathrm{a}$ \\
\hline \multirow[t]{5}{*}{ Stek } & $\mathrm{P} 2$ & $1,38 \mathrm{a}$ & $2,13 \mathrm{a}$ & $6,57 \mathrm{a}$ \\
\hline & P3 & $2,00 \mathrm{ab}$ & $3,38 \mathrm{a}$ & $8,21 \mathrm{ab}$ \\
\hline & P4 & $2,25 \mathrm{~b}$ & $5,13 \mathrm{ab}$ & $9,26 \mathrm{~b}$ \\
\hline & P5 & $2,80 \mathrm{~b}$ & $6,25 \mathrm{~b}$ & $10,93 \mathrm{bc}$ \\
\hline & P6 & $4,38 \mathrm{c}$ & $7,00 \mathrm{c}$ & $12,22 \mathrm{c}$ \\
\hline BNT 5\% & & 1,54 & 2,17 & 2,95 \\
\hline
\end{tabular}

Keterangan: Angka-angka yang diikuti oleh huruf yang sama pada umur pengamatan yang sama yang sama berarti tidak berbeda nyata pada taraf uji BNT $5 \%$.

Umur pengamatan 4 dan 8 minggu setelah tanam pada variabel berat basah stek, perlakuan P6 tidak berbeda nyata dengan perlakuan P5 kecuali dengan perlakuan P1; P2; P3; P4 dan perlakuan P1 tidak berbeda nyata dengan perlakuan $\mathrm{P} 2$; P3; P4 terkecuali perlakuan P5; P6, pada umur pengamatan 12 minggu setelah tanam perlakuan lama waktu perendaman P5 tidak berbeda nyata dengan perlakuan P4; P3 terkecuali dengan perlakuan P1; P2; P6, perlakuan lama wktu perendaman P1 juga tidak berbeda nyata dengan perlakuan P2; P3 terkecuali dengan P4; P5; P6.

Hal yang berbeda terjadi pada variabel berat kering stek di mana umur pengamatan 4 minggu setelah tanam perlakuan P5 tidak berbeda nyata dengan perlakuan $\mathrm{P} 4 ; \mathrm{P} 3$ terkecuali $\mathrm{P} 1 ; \mathrm{P} 2$; $\mathrm{P} 6$ dan $\mathrm{P} 1$ tidak berbeda nyata dengan perlakuan $\mathrm{P} 2$; P3; terkecuali perlakuan P4; P5; P6. Umur pengamatan 8 minggu setelah tanam perlakuan P5 tidak berbeda nyata dengan P4 kecuali P1; P2; P3; P6 dan sebaliknya P1 tidak berbeda nyata dengan P2; P3; P4 kecuali pada P5 dan P6. Umur pengamatan 12 minggu setelah tanam perlakuan P6 (60 menit) tidak berbeda nyata dengan perlakuan P5 (50 menit) terkecuali pada perlakuan lainnya, perlakuan P5 (50 menit) tidak berbeda nyata dengan perlakuan P4 (40 menit); P3 (30 menit) dan P6 (60 menit) terkecuali dengan perlakuan lainnya, sebaliknya P1 (10 menit) tidak berbeda nyata dengan perlakuan P2 (20 menit); P3 (30 menit) kecuali pada perlakuan lainnya. 
Hal ini disebabkan karena diduga bahan stek yang digunakan melebihi umur satu tahun setelah tanam dan sudah pernah berbuah sehingga stek tidak mampu mengabsorsi ZPT dalam waktu perendaman P1; P2; P3; P4 sehingga pertumbuhan stek hanya berpengaruh nyata pada perlakuan lama perendaman P5 dan P6 yang merupakan perlakuan perendaman yang paling lama. Dengan demikian hipotesis 2 terjawab yakni semakin lama waktu perendaman maka semakin optimal pertumbuhan akar dan tunas tanaman vanili.

$$
\text { Menurut Waluyo dalam }
$$

Supardi dan Seda (2010) semakin lama waktu perendaman stek vanili dalam ZPT akan menghasilkan stek vanili dengan kandungan bahan organik dan unsur mineral yang tinggi. Tingginya unsur penyusun stek vanili terjadi karena aktifnya akar penyerap unsur hara dari media tanam. Didukung oleh pendapat Salman (2014) bahwa semakin lama perendaman dengan air kelapa muda akan semakin tinggi volume atau konsentrasi air kelapa muda yang masuk ke dalam biji. Hal tersebut juga diperkuat oleh hasil penelitian Mulyani dan Ismail (2015) yang mengatakan bahwa lama perendaman membuat stek dapat menyerap larutan hormon sampai batas optimum yang dibutuhkan oleh tanaman untuk pertumbuhan dan perkembangannya.
Berdasarkan hasil penelitian respon perumbuhan stek batang vanili (Vanila planifolia) akibat lama perendaman zat pengatur tumbuh root most dapat disimpulkan sebagai berikut:

1. Perbedaan lama perendaman memberikan respon pertumbuhan yang berbeda pada stek tanaman vanili (Vanilla planifolia) persentase pertumbuhan terbaik diperoleh pada perlakuan 60 menit dengan jumlah akar (55,99\%), panjang akar $(58,86 \%)$, diameter tunas $(1,12 \mathrm{~mm})$, panjang tunas $(70,15 \%)$, berat basah stek $(37,14 \%)$, berat kering stek $(65,04 \%)$.

2. Lama waktu perendaman stek batang vanili dalam zat pengatur tumbuh Root Most yang optimum adalah 60 menit (P6) dan terendah diperoleh pada perlakuan 10 menit (P1) pada semua variabel pengamatan

\section{UCAPAN TERIMAKASIH}

Terimakasih yang sebesarbesarnya penulis ucapkan kepada Bapak pembimbing yang telah memberikian kritik dan saran sehingga penelitian ini dapat selesai, terimakasih juga kepada kedua orang tua yang telah mendukung penulis baik secara materi maupun secara moral.

\section{DAFTAR PUSTAKA}

\section{SIMPULAN}


Anonim. 2010. Root Most perangsang pertumbuhan akar. https://www. bukalapak. com.Diakses, 10 Januari 2019

Basmal, J. 2009. Prospek Pemanfaatan Rumput Laut Sebagai Bahan Pupuk Organic.J. Squad, 4 (1) :1-8.

BMKG Kabupaten Ende. 2019. Iklim dan Curah Hujan. https://id.m.wikipedia.org/w iki/Kabupaten_Ende.

Diakses, 23 Agustus 2019.

BPS NTT. 2015.Data Penurunan Produksi Tanaman Perkebunan Tahun 2014.NTT Dalam Angka 2015.

BPS Kabupaten Ende. 2015.Data Penurunan Produksi Tanaman Perkebunan Tahun 2014 .Ende Dalam Angka 2015.

Erona, M. 2016. Pertumuhan Bibit Vanili (Vanilla planifolia A) Trichoderma Harzianum Pada Tanah Ultisol. Skripsi. Bogor Agricultur. Institut Pertanian Bogor, (Tidak Dipublukasikan)

Firmansyah, dkk. 2014. Pengaruh Pemberian IBA dan Komposisi Media Terhadap Pertumbuhan Stek Sansevieria cylindrica var. Patula.J.Scripta Biologica, 1 (2) :161-165.

Gomes, K.C., Gomes, A. 1955. Prosedur Statistik Untuk Penelitian Pertanian.Edisi Kedua.Universitas Indonesia.Jakarta.
Hidayat, A. Y., Hariyadi, 2015. Respon Pertumbuhan Bibit Vanili (Vanilla PlanifoliaAndrews)

Terhadap Aplikasi Zat Pengatur Tumbuh Dan Pupuk Cair Npk. J. Bul.Agrohorti 3(1) : 39-46.

Lingga, P. 1989. Petunjuk Penggunaan Pupuk. PT. Penebar Swadaya. Jakarta.

Mulyadi, C., Ismail, J. 2015. Pengaruh Konsentrasi dan Lama Perendaman Rootone$F$ Terhadap Pertumbuhan Stek Pucuk Jambu Air (Syzygium semaragense) Pada Media Oasis.J. Penelitian, 2 (2) :1-8

Supardi, P, N., Seda,S. 2010. Pengaruh Waktu Perendaman Stek Batang Vanili Dalam Zat Pengaur Tumbuh Rootone-F Terhadap Pertumbuhan Vanili (Vanilla planivolia andrews). J. Agrica, 3 (2) :86-98.

Samadi, B. 2009. Sukses Budidaya Vanili. Angkasa. Bandung.

Suprapto, A. 2004. Auksin Zat Pengatur Tumbuh Penting Meningkatkan Mutu Stek Tanaman. J.Fakultas pertanian. Universitas Tidar Magelang. 21 (1) : 81-90

Salman, I. 2014. Pengaruh Tingkat Kemasan Buah Dan Lama Perendaman Dengan Air Kelapa Muda Terhadap Viabilitas Benih Cabe (Capsium annum L.). Skripsi. Fakultas Pertanian. 
Haman : Respon Pertumbuhan Stek Batang Vanili Terhadap Root Most Universitas Teuku Umar
Meulaboh.

Salisburi, F, B., Ross, C, W. 1995.

Fisiologi Tumbuhan. ITB.

Bandung.

Tage, D. E. 2012. Pengaruh Pemberian Mulsa Jerami
Padi Terhadap

Pertumbuhan Dan Hasil

Tanaman Cabai Besar

(Capsium annum L.).

Skripsi.Fakultas Pertanian.

Universitas Flores Ende,

(Tidak Dipublikasikan). 